\title{
A ERA DOS INQUÉRITOS: LIVROS, LEITURA E LEITORES EM SÃO PAULO, ANOS
} 1920.

\author{
NELSON SCHAPOCHNIK ${ }^{1}$ \\ ORCID: https://orcid.org/0000-0001-7226-4812
}

\begin{abstract}
RESUMO: Este ensaio debruça-se sobre um conjunto de textos publicados em revistas e na imprensa dos anos 1920 por um editor (Monteiro Lobato), um crítico literário (José Maria Bello), um ensaísta (Antonio de Alcântara Machado) e um pedagogo (Manoel Bergstrom Lourenço Filho). Embora não seja possível indicar uma relação dialógica entre a totalidade dos textos, a sua leitura cerrada permite destacar algumas afinidades seletivas entre eles. Este elemento comum traduz-se na busca de instrumentos de sondagem capazes de produzir dados, apontar tendências e projeções, traçar diagnósticos sobre as práticas editoriais e a formação dos leitores na cidade de São Paulo. Atento simultaneamente à referencialidade e aos modos de argumentação empregados por estes mediadores culturais, é possível compreender a tal Era dos Inquéritos como a ascensão de discursos que forjarão uma política cultural visando articular a reflexão sobre os livros e o campo editorial, a formação dos leitores e equipamentos culturais na cidade. Lido de um ponto de vista retrospectivo, a Era dos Inquéritos pode ser considerada como um conjunto de reflexões que forneceram iluminações para a elaboração do programa do Departamento de Cultura e Recreação, dirigido por Mário de Andrade nos anos 30.
\end{abstract}

Palavras-chave: inquérito, livros, leitura, leitores, São Paulo.

\section{THE ERA OF INQUIRIES: BOOKS, READING AND READERS IN SÃO PAULO ON 1920’S}

\begin{abstract}
This essay investigates the published work of an editor (Monteiro Lobato), a literary critic (José Maria Bello), an essayist (Antonio de Alcântara Machado) and a pedagogue (Manoel Bergstrom Lourenço Filho) in both journals and the press during the 1920s. Although a dialogical relation cannot be claimed when one considers the corpus in its totality, some selective affinities among the authors are made evident through a close reading. This common ground turns out to be the search for data gathering, trend projection, and diagnostic tools with regards to editorial practices as well as the making of the readers in the city of Sao Paulo. If one considers both referentiality and argumentative modes deployed by these cultural mediators, it is possible to view the Era of Inquiries as the rise of a discourse that will shape a cultural politics that articulate reflections on books, the editorial field, the readers' development as well as the city cultural equipment. From a retrospective point of view, the Era of Inquiries might be considered an important set of reflections that inspired the creation of the Culture and Recreation Department program directed by Mário de Andrade in the 1930s.
\end{abstract}

1 Docente da Faculdade de Educação, Universidade de São Paulo (FEUSP). São Paulo, SP, Brasil. <nschapo@uol.com.br> 
Keywords: inquiry, books, reading, readers, São Paulo.

\section{LA ERA DE LAS ENCUESTAS: LIBROS, LECTURA Y LECTORES EN SÃO PAULO AÑOS 1920}

RESUMEN: Este ensayo se centra en un conjunto de textos publicados en revistas y en la prensa de la década de 1920 por un editor (Monteiro Lobato), un crítico literario (José Maria Bello), un periodista (Antonio de Alcântara Machado) y un pedagogo (Manoel Bergstrom Lourenço Filho). Aunque no es posible señalar una relación dialógica entre todos los textos, su lectura atenta permite resaltar algunas afinidades selectivas entre ellos. Este elemento común se traduce en la búsqueda de instrumentos investigativos capaces de producir datos, señalar tendencias y proyecciones, hacer diagnósticos sobre las prácticas editoriales y la formación de lectores en la ciudad de São Paulo. A la par que atentos a la referencialidad y los modos de argumentación empleados por estos mediadores culturales, es posible entender la Era de las Encuestas como el surgimiento de discursos que forjarán una política cultural orientada a articular la reflexión sobre el libro y el campo editorial, la formación de lectores y equipamientos culturales en la ciudad. Leída desde un punto de vista retrospectivo, la Era de las Encuentas puede considerarse como un conjunto de reflexiones que iluminaron la elaboración del programa del Departamento de Cultura y Recreación, dirigido por Mário de Andrade en los años treinta.

Palabras clave: encuesta, libros, lectura, lectores, São Paulo. 
Ideias estão isentas de impostos alfandegários. Mesmo assim, há problemas. Karl Kraus, Ditos \& desditos.

\section{INTRODUÇÃO}

Ao analisar $A$ Vida Literária no Brasil, 1900, Brito Broca indicou a emergência de uma nova forma de fazer jornalismo que, no que diz respeito às relações com a literatura, implicava a "decadência do folhetim, que evoluiu para a crônica de uma coluna, focalizando apenas um assunto, e daí para a reportagem" (BROCA, 1975, p. 219), acrescentando ainda a disseminação da entrevista como um recurso investigativo pouco utilizado até aquele momento. O emprego dos questionários como peça-chave das enquetes ou dos inquéritos estava inexoravelmente articulado à busca de uma nova objetividade. Nesse sentido, aquilo que se dava a conhecer não expressava exclusivamente o ponto de vista daquele que chancelava a coluna, mas procurava dar conta dos efeitos polifônicos da opinião pública.

O artigo de João do Rio, "O Brasil lê", publicado nas páginas do periódico carioca Gazeta de Notícias (26/11/1903), pode ser considerado o balão de ensaio deste gênero, que posteriormente ele ampliou e empregou de maneira precursora em O Momento Literário, publicado em 1909 pela Livraria Garnier. Esta obra tinha por modelo a "Enquête sur l'Évolution Littéraire", inquérito promovido por Jules Huret em 1891 nas páginas do $L^{\prime} E$ cho de Paris, reunindo depoimentos de 64 escritores que discutiam a situação do naturalismo na França. No caso de João do Rio, o inquérito valeu-se de entrevistas e de correspondências trocadas com escritores de diferentes correntes literárias finisseculares que foram reproduzidas originalmente nas páginas da Gazeta de Notícias, entre 1904 e 1905. Os depoentes selecionados eram convidados a falar sobre a sua formação e as suas preferências literárias, a tradição e a renovação no campo da prosa de ficção e da poesia, as tensões entre o nacional e o regional e as relações entre o jornalismo e a "arte literária".

$\mathrm{Na}$ década seguinte, essa nova forma do fazer jornalístico espraiou-se para as páginas de outros jornais, indicando a assimilação do inquérito como uma estratégia que permitia pôr em pauta e especular diferentes aspectos do processo de difusão da cultura letrada e da formação dos leitores.

Nesse sentido, é importante recuperar aquela que parece ter sido a primeira enquete promovida pelo jornal O Estado de S.Paulo, em 1914, que tinha por objetivo refletir sobre a situação da instrução pública e de suas necessidades na unidade da federação, sobretudo após as primeiras reformas educacionais introduzidas pelos governos republicanos. Com base em opiniões coligidas a partir de um seleto grupo de dirigentes educacionais, professores e jornalistas, explicitaram-se algumas mazelas experimentadas pelos docentes e os problemas decorrentes da organização escolar (BONTEMPI JR., 2005).

Foi também nas páginas do Estadinho, edição vespertina desse mesmo jornal, que Monteiro Lobato lançou, em janeiro de 1917, uma enquete em que convocava a participação dos leitores para responder algumas questões sobre o Saci, personagem emblemático da mitologia cabocla. As respostas, sob a forma de cartas, vieram dos mais distintos e distantes rincões do País e constituíram matéria-prima para a publicação, no ano posterior, de Sacy-Pererê: Resultado de um Inquérito, que marcaria a sua inserção no mercado livreiro como editor (CAMARGO, 2008).

Não resta dúvida que, por volta dos anos 1920, o emprego deste procedimento foi se consolidando como uma solução bastante positiva para perscrutar diferentes dimensões da realidade. Instrumento de sondagem capaz de produzir dados, apontar tendências e projeções ou, ainda, traçar diagnósticos, ele foi empregado para inquirir o que era publicado em São Paulo, sendo apropriado como Leitmotiv para crônicas de Monteiro Lobato e de António de Alcântara Machado, 
que, sob diferentes enfoques e padrões estilísticos, traçaram ponderações sobre a cultura letrada e o mundo dos impressos. Esse procedimento ainda instigou reflexões de José Maria Belo sobre o significado literário da expansão da produção livreira paulista e, finalmente, se desdobrou em recurso metodológico para a reflexão de caráter pedagógico encabeçada pelo educador Manoel Lourenço Filho, ao analisar as práticas de leitura no âmbito do público escolar. A reconstrução parcial desses inquéritos e comentários também permitiu estabelecer uma conexão entre as respostas e inquietações sugeridas a partir desse conjunto de textos e aquelas ações que vão se transmutar em políticas públicas e culturais implantadas na Pauliceia na década seguinte.

\section{“O QUE SE LÊ EM SÃO PAULO?”}

É com esta chamada que, no dia 3 de julho de 1920, o Estadinho procurou fisgar os leitores e dar conhecimento dos resultados obtidos no inquérito realizado entre 20 casas editorais instaladas na capital paulista. Contudo, a leitura do texto com a apresentação dos resultados da investigação revelava um problema de fundo, que era anterior à própria pesquisa. É notável o equívoco cometido pelo jornalista. Ele partia de um pressuposto tácito, qual seja, a existência de uma analogia entre aquilo que é produzido e distribuído no mercado editorial, por um lado, e as práticas efetivas dos leitores, por outro. Portanto, o que se dá ao conhecimento dos leitores é algo bastante distinto do conteúdo e das expectativas contidas no título da matéria.

De acordo com o relato, é possível vislumbrar que o inquérito foi construído a partir de um questionário simples e objetivo, remetido aos editores. A estrutura do texto parece reproduzir a ordem das questões, a saber: quantas obras foram publicadas em 1920, qual a natureza ou área de conhecimento dos livros editados e a sua respectiva tiragem. Depois de organizar os dados colhidos, somos informados sobre a existência de " 20 casas editoras entre as de maior e de menor importância, representando um capital de cerca de 3.500 contos (de réis), englobadamente". Apesar de a cifra indicar um considerável aporte de investimento, este conjunto não ofuscava a importância e hegemonia da cadeia produtiva do livro instalada na cidade do Rio de Janeiro, capital federal e sede das mais importantes editoras e livrarias, das revistas e jornais de circulação nacional, como também de tipografias, litografias, encadernadoras e de empresas voltadas para a comercialização de insumos para a impressão (papel, tinta, tipos, filetes etc.).

A pesquisa indicava que no ano de 1920 foram publicadas 203 obras, distribuídas por 15 empresas, o que permitiu traçar o seguinte quadro:

Quadro 1 - Editoras e número de publicações, São Paulo (1920).

\begin{tabular}{|l|c|l|c|}
\hline Nome & $\mathrm{N}^{\mathrm{o}}$ & Nome & $\mathrm{N}^{\mathrm{o}}$ \\
\hline Companhia Melhoramento 2 & 35 & C. Teixeira \& Cia. & 10 \\
\hline Paulo de Azevedo \& Cia. & 32 & Empresa Editora Brasileira & 9 \\
\hline Augusto Siqueira \& Cia. & 26 & Lyceu Coração de Jesus & 9 \\
\hline Monteiro Lobato \& Cia. & 15 & A.O. Rodrigues & 8 \\
\hline Livraria Magalhães & 13 & Antonio F. de Moraes & 8 \\
\hline Sociedade Editora Olegário Ribeiro & 12 & Saraiva \& Cia. & 8 \\
\hline D. Silva & 11 & Casa Editora “O Livro" & 5 \\
\hline
\end{tabular}

Fonte: O Estado de São Paulo, reproduzido em "Movimento Editorial”. Revista do Brasil n. 63, mar. 1921, p. $278-280$

O inquérito também indicava que, para além da centralidade verificada na produção editorial instalada na cidade de São Paulo, não seria correto ignorar a existência de uma parcela diminuta de editores ocasionais ou de menor expressão instalados em outras cidades do estado, tais como Santos, Campinas, Ribeirão Preto, São Carlos, Piracicaba, Jaú e Sorocaba. Embora não figurasse no levantamento, o texto não deixa de indicar, por exemplo, a importância da livraria Genaud, instalada em Campinas, que seria responsável por "dezenas de edições de livros infantis, escolares e para adultos". 
Com base nas informações prestadas pelas empresas, o inquérito proporcionou uma radiografia do trabalho editorial, permitindo constatar uma relativa complexificação desta atividade, que se traduzia na existência de editoras voltadas para um determinado nicho do mercado e, portanto, indicando uma crescente diversificação e especialização. Dessa maneira, o mercado editorial transmuta-se em um universo multifacetado, em que as editoras Monteiro Lobato \& Cia. e a Casa Editora "O Livro" se destacavam na área de literatura; a Melhoramentos encaminhava-se para a produção de livros infantis; a Empresa Editora "Chácaras e Quintais" enfatizava o setor de assuntos agrícolas; a Editora "O Pensamento" voltava-se para os temas do ocultismo e espiritualismo; a Empresa Editora Brasileira estava direcionada para os assuntos comerciais; Paulo Azevedo \& Cia., Augusto Siqueira \& Cia. e o Liceu Coração de Jesus atuavam estritamente na produção de livros didáticos, enquanto a Sociedade Editora Olegário Mariano e a Saraiva \& Cia. atuavam em um espectro mais amplo no qual figuravam obras de literatura, livros didáticos, livros jurídicos e assuntos comerciais; e, por fim, a Livraria Magalhães, D. Silva e Antonio F. de Moraes editavam folhetos e obras populares.

A análise dos indicadores referentes ao número de exemplares produzidos no ano de 1920, segundo as declarações dos editores, remontava a um total de 203 obras publicadas, perfazendo uma tiragem de 901 mil exemplares. O desencontro nas informações, sobretudo em decorrência da ausência de comprovação fornecida pelos mapas da edição, contribuiu para certa suspeição. Por isso mesmo, o texto do inquérito admitia a existência de um exagero no que tange à divulgação do número de exemplares tirados, sugerindo um desvio na casa de $10 \%$ do valor indicado. A crer nos dados divulgados pelas editoras, constata-se que pouco mais de dois terços da tiragem total cabem aos livros didáticos. Do terço restante, cerca de cem mil exemplares representam edições de livros de literatura, os demais compreendem as edições de livros de direito, medicina, comércio, conhecimentos úteis, literatura de cordel etc.

De maneira conclusiva, o inquérito procurava indicar o tamanho das tiragens de acordo com a natureza do livro, e assim somos informados que as tiragens dos livros didáticos oscilavam entre 5 mil a 50 mil exemplares por edição; as dos livros de direito, medicina e comércio, entre mil a 2 mil exemplares; as de agricultura tiraram-se de mil a 10 mil exemplares; os livros de literatura de cordel, de 3 mil a 5 mil exemplares; e, por fim, os livros de "boa literatura", entre mil e 4 mil exemplares, sendo excepcional a tiragem de 8 mil alcançada pelo Urupês, de Monteiro Lobato, ou, ainda, a cifra de 6 mil exemplares obtida com os versos de Alma Cabocla, de Paulo Setúbal, e com os contos de Monteiro Lobato, reunidos em Negrinha. A pulseira de ferro, novela de Amadeu Amaral, contou com uma tiragem de 5.200 exemplares, número bastante próximo de Narizinho arrebitado, de Monteiro Lobato.

Pelo que foi exposto, o inquérito não cumpriu o seu fim. De qualquer maneira, é possível inferir que o movimento editorial ali indicado corroborava a forte expansão das matrículas nos estabelecimentos de ensino (ginásios e liceus, o ensino técnico secundário e as escolas normais, entre outros estabelecimentos congêneres implantados no estado de São Paulo), na difusão do livro voltado para os conhecimentos úteis ou mais imediatos (seja para as atividades urbanas ou rurais), como também apontava para a divulgação de autores nacionais. De maneira dissimulada, o inquérito também serviu como um irradiador das virtudes e potencialidades de Monteiro Lobato, não apenas do autor de literatura para adultos e crianças, mas, sobretudo, do editor capaz de forjar um projeto editorial e se dedicar exclusivamente à edição de livros.

Por isso mesmo, não parece ser casual que o inquérito tenha sido reproduzido nas páginas da Revista do Brasil, que era dirigida pelo próprio Lobato, como também foi o elemento deflagrador de reflexão sobre "os livros fundamentais", publicado pelo escritor em Onda Verde (LOBATO, 1957, p. 83-88; LUCA, 1999).

\section{CONSIDERAÇÕES LOBATIANAS SOBRE O INQUÉRITO DE O ESTADINHO}

O ensaio de Monteiro Lobato inicia-se com duras palavras a propósito do inquérito realizado pelo "filhote vespertino do Estado". De acordo com o dublê de escritor e editor, "Tais 
inquéritos são por natureza deficientes e velhacos, intervindo para viciá-los não só a maroteira dos negociantes, como ainda a simpatia dos promotores. Além disso não comprovam o que se lê, senão, e apenas, o que se compra.”. Reiterando o pressuposto tácito que alimentava o inquérito, ele advertia que muita gente adquiria os Ensaios de Montaigne, as obras de filosofia de Platão e Nietzsche, ou os volumes de Taine, Spencer, Mommsen e William James apenas para divulgar a aura de leitor de grande cabedal, emblematizada pelos elegantes volumes dispostos nas prateleiras das respectivas bibliotecas privadas. No entanto, na intimidade do quarto, "à cabeceira da cama, só lhes vereis o velho Dumas ou o moderno Nick-Carter" - o que lhe permite concluir com uma tirada bastante sarcástica: "De modo que tais inquéritos erram de objetivo e tomam a nuvem por Juno, como se dizia nos saudosos tempos das imagens gregas". Nesta abertura em tom maior, Lobato desfere uma bofetada na chamada cultura ornamental e na distinção entre os livros concebidos como objetos de exposição, que transferiam para o seu proprietário predicados desejáveis, e faz menção ao que se dava de fato à leitura, marcada pelo antagonismo entre a "velha" fórmula do romance edificante e a "moderna" narrativa policial.

É também com uma agudeza crítica que Monteiro Lobato se recusava a universalizar e pasteurizar os hábitos de leitura entre a população paulistana. Ainda que o seu argumento repouse num binarismo quase que maniqueísta, ele asseverava a necessidade de "distinguir o que lêem os trezentos de Gedeão do escol nacional, do que lê a massa, os 99\% do país". De maneira bastante enfática, Lobato destacava a atitude de emulação presente entre os hábitos de leitura das classes abastadas, atitude que revelava um falso cosmopolitismo e que era traduzida pelo gosto literário identificado com autores como Anatole France, Maupassant, Maeterlinck, Rostand ou ainda o "d'Annunziozinho". O arrivismo intelectual demonstrado por este segmento representava uma cultura de caráter postiço, descolada da realidade nacional. Aliás, ele asseverava que "nada a distingue da elite de toda a parte. A cultura uniformiza os cérebros", para concluir com um juízo bastante severo:

O escol não possui individualidade marcada, nem a coragem do gosto pessoal. Rege-o em toda parte o mesmo código de snobismo... Zelosos do bom-tom, vestem o cérebro pelo figurino do dia, e usam um poeta, um romancista, um filósofo, do mesmo modo e pelas mesmas razões que usam um certo nó de gravata ou tal moda de chapéu (LOBATO, 1957, p. 84).

Como se vê, Monteiro Lobato indicava uma perspectiva disfórica em relação às formas conspícuas de consumo cultural praticadas pelas elites. Embora não renegasse a importância da tradição e do cânone ocidental na formação dos leitores, Lobato sublinhava que esse protocolo, na maioria das vezes, significava uma tola adesão, especialmente porque denotava um artificialismo cujo resultado efetivo nada acrescentava à cultura brasileira. Por esse motivo, sua atenção se voltaria para outro segmento, aquele representado pelo "povo", com especial deferência ao público infantil. Diferentemente da afetação e do arrivismo presentes nos hábitos culturais das classes abastadas, o escritor exaltava a singeleza da cultura letrada de extração popular nos seguintes termos: "o povo tem a coragem da sua honrada estupidez. Veste-se como quer e lê o que lhe sabe".

Este elogio arrevesado estava assentado na constatação de que aquilo que se oferecia aos estudantes de primeiras letras no âmbito escolar era incapaz de forjar bons leitores. O seu ceticismo resultava da observação de que os modos de aprendizagem da leitura eram desestimulantes, em grande medida porque assentados na memorização de listas de datas, acidentes geográficos e de personagens de um panteão cívico que pouco ou nada sensibilizava os jovens leitores. Daí afirmar:

O menino aprende a ler na escola e lê em aula, à força, os horrorosos livros de leituras didáticas que os industriais do gênero impingem nos governos. Coisas soporíferas, leituras cívicas, fastidiosas patriotices, Tiradentes, bandeirantes, Henrique Dias, etc. Aprende assim a detestar a pátria, sinônimo de séca, e a considerar a leitura como um instrumento de suplício (LOBATO, 1957, p. 84). 
O argumento beligerante de Lobato também indicava a existência de um elemento inercial nas relações entre os editores de livros escolares e/ou didáticos e as instâncias oficiais, responsáveis pela aprovação, a recomendação ou, ainda, a compra de exemplares para a distribuição nas escolas. O resultado perverso desse circuito, em que se mesclavam estratégias pedagógicas questionáveis e interesses comerciais explícitos aliados a uma fôrma cívica malacabada, configurava um quadro bastante negativo, que não por acaso ele alcunhou de "pátria de fancaria empedagogada em estilo melodramático". O que Lobato parece sugerir é que as diretrizes empregadas na formação dos leitores acabavam por sacrificar qualquer capacidade de considerar usos positivos e mobilizadores dos valores associados à pátria e ao civismo. Diante da alegada incapacidade de estimular a observação e de despertar a imaginação infantil, os conteúdos abordados passariam a ser vistos como uma abstração desagradável, um verdadeiro castigo que repercutia naquele atributo identificado com as competências da prática escolar, resultando em um corolário nefasto: "a leitura é um mal, o livro, um inimigo; não ler coisa alguma é o maior encanto da existência".

Mas é quando ele se volta às práticas de leitura no contexto extraescolar que se evidenciam os sentidos dos "livros fundamentais" aludidos no título do ensaio. O procedimento adotado por Lobato foi por ele denominado de "seriação da leitura". Tal recurso designava a eleição de um determinado título, alçado à condição de representativo, em um momento da formação do leitor. Assim, os tais "livros fundamentais" são peças de uma tipologia ideal, que lhe permite traçar uma homologia entre a vida do leitor e os protocolos de leitura, apresentados como estágios ou etapas que remetem ao percurso de uma vida, da infância à maturidade, agregando certas qualidades narrativas, despertando efeitos e ampliando as habilidades interpretativas. O seu argumento é quase impressionista e por demais genérico, assentando-se na capacidade evocativa da memória e na força da tradição. De acordo com o ensaísta: "Mil cidadezinhas pelo interior do Brasil existem onde, em matéria de leitura, de pais a filhos, gerações sucessivas gravitam em torno desse trio, Teresa, Carlos Magno, Escrich".

A afirmação sobre a presença difusa da obra licenciosa e/ou libertina setecentista Teresa, filósofa nas bibliotecas privadas parece ser de saída um dado questionável, embora plausível ${ }^{2}$. De qualquer maneira, esse livro ideal, que ensejava um padrão de leitura escusa, teria um grande mérito que, de acordo com Monteiro Lobato, possibilitaria ao jovem:

ver que a letra de forma não se limita a veicular as estopadas bocejantes do desagradável tempo de prisão escolar; (...) que a leitura é suscetível de interessar profundamente à imaginação; e que se há livros piores do que palmatórias, há em compensação deliciosos como esse da boa Teresa (LOBATO, 1957, p. 85).

Por sua vez, o lugar que a narrativa de Carlos Magno e os Doze Pares de França teria enquanto livro formador se justificava por despertar o espírito guerreiro ou a imaginação épica no jovem leitor. O contato com essa obra, de há muito multiplicada por diversas edições, sob a forma de cordel, ou ainda, como romance, balizaria o percurso formativo dos leitores nos caminhos pela "boa estrada". Com efeito, ele registrava:

a imaginação ali cabriola como potro insofrido, liberto da baia. Aqueles heróis que fendem cabeças de mouros durante trezentas páginas a fio, o cheiro de sangue que exala

\footnotetext{
2 De acordo com Alessandra El Far, a novela de Boyer d'Argens circulou por estas terras sob a forma de edições populares provenientes da França e de Portugal, mas também figurou entre os "livros baratíssimos" editados no Rio de Janeiro e comercializados pelos livreiros à margem do comércio chique da Rua do Ouvidor. A obra Teresa, filósofa também pode ser evocada como uma das matrizes ou modelo narrativo apropriado para a elaboração dos abundantes "romances de sensação" que circularam no período finissecular (EL-FAR, 2004, p. 270-272).

${ }^{3}$ Conforme registrou Marlyse Meyer: "Fixado em livros, mas também em folguedos, a lembrança de Carlos Magno impregna memórias, escritas ou orais, 'letradas' ou 'populares', embala sonhos e encantamentos das crianças”. (MEYER, 1993, p.149)
} 
a história, as façanhas inauditas dos invencíveis pares de França, tudo aquilo por junto forma um amavio inebriante, capitoso como um vinho forte (LOBATO, 1957, p. 86).

Por fim, a leitura de Perez Escrich para as meninas e Casimiro de Abreu para os meninos corresponderia à chegada da puberdade, cujo efeito mais imediato seriam as perturbações decorrentes da "aurora do primeiro amor".

Como se não bastasse destacar as qualidades intrínsecas dessas obras e desses autores, como também sublinhar os efeitos na imaginação dos jovens leitores, Monteiro Lobato reiterava a presença dos livros no interior das moradas dos mais distintos pontos do País. A menção à sua distribuição pelos espaços domésticos ("em cima das cômodas, na gaveta dos toucadores, nos cestinhos de costura"), aos atributos materiais dos livros ("páginas amarelecidas e encardidas"), de suas marcas de uso ("cantos puídos e folhas uma a uma assinaladas com dobrinhas marcadoras de interrupção da leitura", ou, ainda, "chegam literalmente a gastar-se, como velhas notas de mil reis"), corroborava a inferência acerca da existência de um diminuto patrimônio bibliográfico coletivo ("alçam-se tais livros à categoria de entidade veneráveis, dignas de maior respeito. Sem donos, em geral, circulam de mão em mão, em empréstimos sucessivos, como bens pertencentes à comunidade").

Lobato encerrava os seus comentários destacando o desprestígio que as letras nacionais exerceram entre os hábitos de leitura popular, uma vez que os livros formadores "vieram da península, com a pimenta e o queijo do reino", exceção feita às Primaveras, atribuída sarcasticamente a "Casimiro Patativa", talvez para sublinhar a mescla do elemento recitativo e o tom langoroso do poeta romântico. Diante deste quadro pouco favorável, ele asseverava de maneira cabal que:

\footnotetext{
Só nacionalizamos, portanto, o amor - e o amor masculino, apenas. Para o resto o nosso povo ainda é colono. E assim será enquanto a literatura for entre nós planta de estufa desabrochada em flores como as quer a elite, e enquanto a pedagogia por a própria arte de secar as crianças com o didatismo cívico, criando, logicamente, o irredutível horror à leitura que caracteriza o brasileiro (LOBATO, 1957, p. 88).
}

A força do diagnóstico traçado por Lobato parece ter um efeito autopromocional, uma vez que indicava elementos prescritivos que espelhavam as suas estratégias autorais e empresariais. Dessa forma, a publicação do "Inquérito" nas páginas da Revista do Brasil e a redação desse ensaio podem ser lidas como peças de um mesmo circuito que procurava legitimar o seu lugar no mercado de bens simbólicos, como o editor responsável pela divulgação de uma literatura infantil nacional, na qual ele mesmo aparecia como autor, tradutor e adaptador (BIGNOTTO, 2018). O sucesso alcançado naquele momento pela editora Monteiro Lobato \& Cia. e as expressivas vendagens dos títulos escritos e publicados ali também ofereciam uma resposta para o repudiado "didatismo deformador" (NAGLE, 1976, p. 250).

\section{SAPO DE FORA CHIA OU NÃO CHIA?}

O inquérito promovido pelo Estadinho e replicado na Revista do Brasil repercutiu para além das fronteiras paulistas. Responsável pelo rodapé "Vida Literária" que integrava as páginas d'O Jornal, José Maria Bello, pernambucano que naquele momento respondia pela biblioteca da Câmara dos Deputados, não só atestava o vigor da publicação como também, de maneira bastante sagaz, explicitava a consonância entre o veículo e o seu proprietário, quando sublinhava que a revista "congratula(va)-se consigo mesma pelo auspicioso movimento literário de São Paulo, e que tão bem se traduziu nas sucessivas edições de Monteiro Lobato \& Comp.” (BELLO, 1922, p. 123).

A saudação dos resultados do inquérito era acompanhada de um arrazoado histórico que procurava justificar as razões para a "extraordinária e auspiciosa florescência literária" verificada na Pauliceia. De acordo com Belo, durante os últimos anos do Império e durante toda a República, "intensificava-se o cultivo das letras, boas ou más, gordas ou finas" no Rio de Janeiro, 
na Bahia e em Pernambuco, enquanto os "homens práticos" de São Paulo se esforçavam para promover o crescimento econômico alicerçado na cafeicultura. Do seu ponto de vista, a "vida mental do país ficava a cargo, dos nortistas ou dos provincianos de origens várias, que se aglutinavam no Rio, à sombra protetora do Estado", ao passo que o triunfo do trabalho e da nova configuração da realidade material em São Paulo favoreceu a conquista da hegemonia econômica e política no âmbito federativo.

A recepção do inquérito por parte do crítico denotava a ascensão cultural paulista, fruto da reordenação das relações entre a vida material e a produção cultural. Dessa maneira, ele indicava que o grande movimento literário de São Paulo, traduzido em um vigoroso número de títulos, tiragens, editores e autores, expressava a conquista de um novo patamar cujo significado mais imediato seria a reivindicação e o posterior reconhecimento do lugar que a cidade de São Paulo passaria a ocupar enquanto um polo de produção cultural. Contudo, ele captou outra possibilidade de interpretar os dados da pesquisa, que permitia agregar ao dinamismo da produção cultural o desejo latente de fazer com que as novas experimentações literárias passassem a ser lidas como manifestação da hegemonia literária reivindicada pelos autores lá radicados.

Embora admitisse que os limites do seu conhecimento não permitiriam questionar os dados revelados pela enquete, ele não só capitulava como também reconhecia o mérito de:

Três ou quatro poetas ou escritores, cujos livros tive a ventura de conhecer, num comércio mais íntimo, o sr. Amadeu Amaral, o sr. Menotti del Picchia, o sr. Monteiro Lobato, dos admiráveis Urupês e o ironista do Professor Jeremias, deram-me, de fato, excelentes amostras do talento e da capacidade literárias das modernas gerações paulistas (BELLO, 1922, p. 124).

A explicação para tal triunfo repousava em um argumento longevo, de grande adesão no âmbito da crítica literária e identificado com os pressupostos da chamada Geração de 70. Tratase daquela concepção de inequívocas marcas spencerianas forjada para explicar a relevância de São Paulo na marcha da civilização brasileira. Mesclando elementos evolucionistas e outros tantos de inspiração no determinismo geográfico, ele traçava uma analogia entre a nova corrente responsável pelo processo de "integralização moral e mental do Brasil", identificada com a produção literária editada em São Paulo, com a outrora "integralização geográfica" realizada pelos bandeirantes. Foi com base nesta aproximação e aclimatação de ideias que ele traçou ponderações acerca do significado da nova literatura paulista, caracterizada pela "tendência para um regionalismo romântico", explicada de maneira mais minuciosa nos seguintes termos:

\footnotetext{
Na história sem brilho e nos costumes ingênuos do velho 'caipira' das margens do Paraíba procuram os escritores e poetas paulistas os motivos de inspiração. Para o pobre Jeca Tatu, vencido sem luta, abandonado ou esquecido nas suas terras cansadas do norte, voltam-se, através de todas as ironias e todas as 'maldades' literárias, as melhores simpatias do sr. Monteiro Lobato. No Dialeto Caipira desconta o sr. Amadeu Amaral a sua ternura regionalista. No poema Juca Mulato, canta o sr. Menotti del Picchia os amores infelizes do mestiço, que São Paulo quase não mais conhece, como o sr. Cornélio Pires, aliás de geração anterior, revivera nos seus contos regionais, o caipira clássico a que o contato diário do ‘colono' estrangeiro vem emprestando outros sentimentos e outra língua (BELLO, 1922, p. 125).
}

Para José Maria Bello, a literatura que se fazia em São Paulo, naquele momento, não expressava novidade alguma e tampouco poderia servir de esteio para propagar a sua superioridade. Em grande medida, ele justificava, porque a "revivescência do espírito regionalista" também era explorada em outros pontos do País. Para fundamentar o seu argumento, ele sublinhava que, entre os impressos que obtiveram êxito no comércio livreiro na capital federal no ano anterior, figuravam obras de "tradições, de contos, de versos, de folclore regionais".

Com muita perspicácia, Bello desdenhava a potencial identificação entre o retorno de "inspirações nativistas", verificada nesta literatura regionalista, como uma resposta 
simultaneamente criativa e repulsiva em relação à emulação e ao pastiche da literatura francesa praticada por muitos escritores brasileiros. Pior, ele asseverava que o tom nacionalista ali presente, "muitas vezes tocado de jacobinismo, que surgiu aqui depois da guerra", não era nada mais, nada menos, do que uma imitação disfarçada daquilo que também era praticado na França. Portanto, aquela experimentação literária expressava um modismo, uma configuração efêmera, que não teria "nem pode ter raízes profundas ou condições próprias de viver".

O crítico declarava com todas as letras que o intenso movimento das livrarias paulistas e cariocas não lhe despertava grande entusiasmo e, além disso, acrescentava que "a quantidade dos autores não corresponde à qualidade". Segundo ele:

A literatura 'caipira' será sempre uma curiosidade. O Brasil não está no Jeca Tatu, nem no Mané Chique-Chique, nem no caipira paulista ou mineiro, nem no sertanejo nortista, poeta e herói, do sr. Catullo ou do sr. Leonardo Motta. Não o sentiram ainda os nossos homens de letras, como não o sentiu ainda a lamentável miopia dos políticos, que tanto se esforçam por estrangula-lo com os seus erros econômicos e as suas eternas ameaças de caudilhismo e de militarismo, talvez porque ele se encontra no seu grande momento de transformação social (BELLO, 1922, p. 127).

As reflexões de José Maria Bello, inspiradas na leitura do inquérito, apontavam para alguns impasses experimentados por escritores, artistas, editores e críticos no intuito de suplantar a sensação de incompletude e de vida cultural imitativa, considerados como um obstáculo para traçar uma representação positiva da brasilidade. Longe de refutar ou menosprezar os esforços perpetrados pelos autores arrolados no ensaio, ele ponderava que "não era justo exigir-se uma literatura acabada e definida num país onde nada ou pouco existe de definido" e apostava no papel triunfante da "missão histórica de guia da nacionalidade" atribuído a São Paulo.

\section{LÁ E CÁ: POR QUE NÃO QUEIMAR OS LIVROS?}

No dia 9 de outubro de 1926, António Alcântara Machado divulgou mais um solo de "saxofone", denominação que ele atribuiu ao rodapé que publicava semanalmente no Jornal do Commercio, edição paulistana. Naquela oportunidade, o mote empregado para iniciar o texto foi o inquérito aberto pelo escritor Marius Boisson, publicado no periódico cultural parisiense Comoedia ${ }^{4}$. $\mathrm{O}$ tema do inquérito dirigido aos literatos franceses era um tanto bizarro: consistia em indicar qual o livro que deveria ser queimado como castigo pelos estragos causados à humanidade. De acordo com Alcântara Machado, a conclusão a propósito da enquete era esta: "todos os livros desde a Bíblia devem ir direitinho para o fogo menos está claro os da autoria dos interpelados".

A leitura do rodapé confirma que a menção ao inquérito francês por parte do escritor paulistano era tão somente um Leitmotiv para introduzir a discussão sobre o que se lia nesta latitude. Daí ele não pestanejar e apresentar rapidamente o seu veredito:

Do ponto de vista brasileiro a resposta seria a mais simples possível: nenhum. Evidente. Não há livro que já tenha conseguido ou consiga impressionar maleficamente o espírito brasileiro.

Por que isso? Homessa porque o brasileiro não lê. Aí está. (MACHADO, 1983a, p. 174).

Para além da perspectiva referencial, o solo de Alcântara Machado revela o emprego, com maestria, de uma série de procedimentos compositivos que podem ser rapidamente identificados com a harmonia modernista, tais como: o uso de frases breves, a apropriação da linguagem coloquial, a presença do humor, da paródia e da ironia, a bricolagem de textos e de pontos de vista, entre outros. Importante sublinhar que esses procedimentos se emolduravam de maneira adequada aos limites materiais impostos pelo editor. Contudo, a forma e o tom

\footnotetext{
4 O periódico foi fundado por Henri Desgrange. De 1919 a 1937, tinha periodicidade diária; entre os seus
} colaboradores, destacam-se nomes expressivos como Jean Cocteau e Guillaume Appolinaire. 
empregados conferiam um novo aspecto à convenção do rodapé como espaço do fato diverso e da crônica, sem abandonar as exigências do entretenimento e da leitura fácil.

$\mathrm{O}$ argumento sobre a incivilidade é todo pautado em fórmulas de exagero, senso comum e humor. A combinação desses ingredientes funcionava e transformava-se em um argumento persuasivo. Veja-se, por exemplo:

\footnotetext{
Não lê mesmo. É inútil. Não há meio de obriga-lo a abrir um jornal quanto mais um volume. Vê lá se ele cabe nessa asneira. Não tem tempo para perder com bobagens. Isso de ler é coisa que não rende. Antes seguir a dezena do elefante três meses seguidos. Ao menos a gente arrisca abiscoitar uns cobres.

Sujeito lido é sujeito pedante. Metido a irônico. Sabe falar francês. Caçoa do próximo. Cita Olavo Bilac. Tem diploma. Faz discursos. Amola os outros. (MACHADO, 1983a, p. 174).
}

Como se vê, Alcântara Machado parece reiterar uma série de tópicas sobre os efeitos negativos da leitura. Ela é uma prática social excludente e de pouco enraizamento social, é identificada como uma atividade não pragmática, isto é, que não agrega valor. Como se isto não bastasse, aquele que a pratica é descrito como portador de qualidades desairosas. Em matéria de educação literária, continuava ele, afirmava a predileção dos leitores pelos livros ilustrados, revisitava a tese de que a leitura poderia estragar a visão, como também de que as "ideias de romance" produziriam desvios comportamentais nas leitoras. A enumeração crescente de malefícios suscitados pela leitura atingia o paroxismo quando se referia à recomendação professoral para que os alunos lessem as obras de Coelho Neto. E concluía esta seção com um período telegráfico, que sintetizava tudo aquilo que ele havia afirmado: "O que é muito pior. Perigosíssimo. Acachapante. Catastrófico. Fim de tudo.”

Na sequência, Alcântara Machado parece reconhecer o exagero das afirmações ao admitir que "há gente que lê sim". E, para tanto, sugeria um inquérito com o intuito de verificar quais seriam os autores de maior predileção ou, em suas palavras, "indagar diretamente dos que nesta terra onde as aves gorjeiam diferente que se dão à leitura quais são os seus livros de cabeceira". De acordo com Alcântara Machado, esta operação deveria incluir entre os depoentes "os fardados da Academia Brasileira de Letras, os machistas da Central (sic) ${ }^{5}$, os diretores das associações de classe, as professoras normalistas, os homens do governo, os acendedores de gás e os cabos do exército", compondo um grupo heterogêneo que satisfazia os critérios de diversidade social, intelectual e de gênero. Mais uma vez, a desconstrução daquilo que foi exposto evidenciava a impertinência da proposta e o recurso da ironia, posto que, antes mesmo de ser levado a cabo, o inquérito era anunciado como "engraçadíssimo", e as respostas dos entrevistados, como "pândegas". Uma vez concluído o levantamento dos questionários, afirmava que "a gente reunia todas as respostas num volume bem grosso editado pelo Quaresma com este título: Porque nos ufanamos da nossa Terra de Santa Cruz Credo. Miguel Meira escreveria o prefácio. Ou Antonio Austragésilo. Indiferente". Obviamente, a proposta editorial trazia implícita uma boa dose de sarcasmo e uma série de divertidas inversões. Inicialmente, a referência ao livreiro e editor Pedro da Silva Quaresma, que se notabilizou por publicar livros de apelo popular (livros práticos, cancioneiros, trivialidades e literatura infantil) em pequeno formato e vendidos por preços baratos, era uma forma zombeteira de desqualificar aquele produto editorial resultante do inquérito, por oposição aos artefatos saídos daquelas editoras que gozavam de mais respeitabilidade, como a Garnier ou a Francisco Alves (HALLEWELL, 2005, p. 274). Por sua vez, o título sugerido burlava a obra do conde monarquista Afonso Celso, Porque me ufano do men país, suprassumo do nacionalismo cívico (BASTOS, 2002), e introduzia um veio negativo derivado da interjeição de repulsa àquela denominação empregada por diversos cronistas que se referiam à América portuguesa como Terra de Santa Cruz. Ademais, juntava com indiferença a menção aos potenciais autores do paratexto editorial.

\footnotetext{
${ }^{5}$ Não seriam os "maquinistas"? (NS).
} 
Ao longo do artigo, percebe-se a vigência de modulações sucessivas de tom, em que o aspecto jocoso e o emprego da ironia dão lugar ao uso de asserções mais sérias e contidas, para logo adiante sofrerem um novo revertério. É isto que se observa imediatamente após as considerações sobre o inquérito acima mencionado, quando lançava um argumento irrefutável e certeiro: "Não basta ensinar a ler. O essencial é ensinar o que ler". E, na sequência, ele agregava o período: "Que adianta a um guri nacional aguentar com três anos de grupo escolar se a primeira cousa que lhe dão para soletrar (e o que é pior para decorar) é o Ouviram do Ipiranga as margens plácidas do incrível Osório Tudo Estraga? Antes continuar analfabeto".

As diferentes situações traçadas ao longo da crônica indicam o paradoxo entre os elevados fins atribuídos à operação da leitura e aquilo que efetivamente faziam os leitores. Para exemplificar os sucessivos desencontros, ele mencionava o tom "asnático" dos livros escolares adotados no Brasil, que "para começar chamam-se epítomes". Ridicularizava a biblioteca dos administradores e parlamentares, "essa gente que legisla sobre educação", cuja dimensão diminuta permitia alocá-la em uma única estante, reunindo livros para serem vistos e "uma obrinha de Gustave Le Bon que é para citações". A leitura de romances franceses pelas meninas, que têm por hábito "ver primeiro como concluem para saber se vale a pena a leitura deles. Se o final não é de fita de cinema não prestam". Ou ainda a preferência dos rapazes pelas "cousas pornográficas e escandalosas. Romances da vida real. Quanto mais cocaína melhor...Decoram Vargas Vila. Acham Machado de Assis uma besta".

Diante desta acumulação de problemas insolventes, de privações e de vícios decorrentes de uma deliberada ausência de políticas culturais, o diagnóstico oferecido era mesmo desalentador. E, assim, o cronista prosseguia arrolando a inanição das revistas literárias, a impossibilidade de fazer das letras profissão, posto que o ato de publicar era análogo àquele experimentado pelo mercado financeiro, isto é, o lançamento de títulos novos se assemelhava a um "banco que emitisse notas sem circulação. É fatal e iminente a falência". Na mesma direção, Alcântara Machado sublinhava a situação vexatória do mercado livreiro nacional, no qual o livro de maior sucesso naquele momento, Noções de arte culinária de D. Maria Tereza da Costa, alcançava a sua décima segunda edição - ao passo que, nas tiragens dos livros de poesia ou de contos, se empregava uma estratégia ardilosa, que consistia em dividir "uma edição de mil exemplares em três: até quatrocentos primeira edição; de quatrocentos a seiscentos segunda; de seiscentos a mil terceira. O povo fica convencido que lê e o autor tem a ilusão que é lido".

Retomando o Leitmotiv, Alcântara Machado afirmava que aqui na terra brasilis seria indiferente a existência ou não de livros "diabólicos e maléficos". Na verdade, os tais livros eram inofensivos, uma vez que o analfabetismo grassava de maneira contagiante, e os poucos capazes de os ler, "não compreenderão patavina". Com uma imagem surreal, ele advertia os seus leitores:

\footnotetext{
Não pensem que eu prego a supercultura não. Deus nos livre de tal desgraça. Crianças nascendo já com óculos e alternando a mamadeira com Spencer. Uma inflação de axiomas e sentenças estragando o mercado intelectual do país. Mulatos de fraque discutindo Freud. Shakespeare por amadores em Santa Rita do Passa Quatro, Deus nos livre. Seria horrível. Mataria o sertão. Mataria a paisagem. Mataria o Brasil. (MACHADO, 1983a, p. 178).
}

O excerto é desconcertante e, apesar de renegar apego à "supercultura", revelava um inequívoco ranço elitista. Contudo, esta imagem parecia funcionar como um exagero deliberadamente forjado para questionar o suposto cosmopolitismo identificado com os "estrangeiros mais ou menos sabidos que nos visitam à nossa custa". Sem deixar de reconhecer os dilemas que afetavam as práticas da leitura e a produção literária nacional, Alcântara Machado intui que a "escuridão", a "ignorância" ou ainda a vergonha resultante do embate com as ideias vindas de fora seriam uma forma reativa que expressava um certo sentimento de menoridade ou passividade crítica. Esta situação foi objeto de severas reprimendas por parte dele, quando afirmava categoricamente que: 
(...) Qualquer manifestação de inteligência vinda de fora assombra os bobos do Brasil. O pouco de cultura que por aí existe já está podre tão velho. É imprestável. As ideias embarcam na Europa em canoas a remo. Levam anos para atravessar o Atlântico e daqui não sai nenhuma. Nem para o consumo interno se fabrica esse artigo quanto mais para exportar. (MACHADO, 1983a, p. 178).

Ao invés de enxergar no elemento estrangeiro a fonte de salvação para a situação de atraso, o crítico enfatizava que as raízes do descompasso deveriam ser buscadas aqui mesmo. E, dessa maneira, ele reconhecia: "o que se lê no Brasil pode-se bem avaliar pelo que se escreve. Ainda mais: no que se escreve é que se encontra o motivo da aversão nacional à literatura". Portanto, diante do acirramento de militâncias que estabeleciam o desapego em relação ao passadismo, o credo no nacionalismo cívico ou ainda a reinvenção nacional por meio da deglutição antropofágica da cultura europeia, Alcântara Machado expressava o seu inconformismo e parecia se recusar a oferecer fórmulas e preceitos, valendo-se mais uma vez da ironia enquanto programa ou plataforma para enfrentar os paradoxos da produção cultural no Brasil. E arrematava a coluna com um desconcertante grand finale:

O problema não tem mesmo solução. Mas como Cristo nasceu na Bahia, meu bem, e é, portanto, brasileiro, (e quem sabe até se mulato) agarremo-nos com ele. Um dia isso endireita. Por que não? Os milagres de hoje são tantos que ninguém mais os percebe. Mas eles existem. Olhem São Paulo com oitocentos mil habitantes por exemplo. (MACHADO, 1983a, p. 179).

\section{“SALVEMOS O PORVIR, MEUS SENHORES"}

Alguns meses após ter dedicado o solo de seu saxofone aos problemas da leitura e da edição em São Paulo, Alcântara Machado voltava à cena. Desta vez ele informava o público-leitor sobre a mudança de instrumento em função de ter encontrado nas páginas da revista francesa $L a$ Nouvele Revue Française uma pequena resenha do livro René Bizet, que empregava, no título, o mesmo nome do instrumento que ele empunhava nos rodapés de sábado, publicados nas páginas do Jornal do Comércio. Este achado indispôs o escritor, resultando em um esclarecedor desabafo: "Ora ninguém gosta de passar por plagiário ou cousa que o valha. Sobretudo quando não o é. Tal é o meu caso. Portanto e como brasileiro não se aperta, ponho de lado o saxofone sem pátria e empunho contente da vida o cavaquinho nacional" (MACHADO, 1983b, p. 192). Obviamente, a mudança de instrumento implicou uma alteração do timbre, mas não afetou o tom, que se manteve irônico e contundente.

Com o singelo título "Pela gurizada", Alcântara Machado iniciou a coluna sondando a formação dos jovens leitores, empregando para tal as suas próprias memórias. Conforme registrou,

Foi com certeza devorando o Tico-Tico que o pessoalzinho da minha idade tomou gosto pela leitura. Como aconteceu comigo. A gente todas as quartas-feiras apanhava dos irmãos mais velhos e dava nos irmãos mais moços só pela febre de ser o primeiro a saber das novas aventuras da família Zé Macaco, Faustina, flor de caju, era nesse tempo a dama dos nossos pensamentos. Porque provocava a nossa alegria. (MACHADO, 1983c, p. 258).

Como que reconhecendo no Tico-Tico um primeiro degrau na escalada formativa do leitor, ele acrescentava que, esgotada a revista, o seu sucedâneo seriam os romances policiais de Nick Carter e as aventuras de Búfalo Bill. O patamar seguinte corresponderia à leitura das obras de Henryk Sienkiewicz, vencedor do Nobel de Literatura em 1905 e sócio correspondente da Academia Brasileira de Letras. Neste rol figuravam A ferro e fogo, O dilúvio, Os cavalheiros da Cruz e Quo V adis, ressalvando que a leitura deste título "só às escondidas", porque teria "um trecho muito imoral". 
Contudo, Alcântara Machado não demonstrava interesse em avançar no esboço dos degraus sucessivos. A coluna, ou a partitura do seu solo de cavaquinho, tinha por tema a discussão das melhores soluções materiais e editoriais para ampliar o horizonte de leituras da gurizada. Além de funcionar como uma estratégia discursiva, simultaneamente afetiva e fática, a menção às "peraltagens hebdomadárias do Chiquinho", personagem do Tico-Tico, indicava uma opção deliberada por parte do cronista na defesa da revista ou do jornal infantil como a melhor forma de estimular a leitura dos jovens.

Comparada com a forma livro, a revista seria portadora de inúmeras virtudes, entre as quais destacava a "leitura mais fácil, mais variada, mais atraente". E, como se não bastasse, ele ainda acrescentava a positividade da seriação ("de sete em sete ou de quinze em quinze dias vai ao encontro dos tampinhas") e a sua amplitude, posto que nela tudo cabe, isto é, "histórias, caricaturas, problemas e cousas do estilo".

É com base no reconhecimento destas potencialidades que Alcântara Machado inverteu o argumento tácito acerca da perenidade do livro, quando confrontado com a fugacidade do jornal. Segundo o cronista, apesar de reconhecer o caráter edificante das "lições de moral e de cousas", por exemplo, divulgadas nas obras escolares de João Kopke, a sua eficácia e permanência eram limitadas. O emprego do livro remetia à tradição da leitura impositiva praticada no ambiente escolar, estabelecendo uma inequívoca associação entre a leitura do livro e a instrução. O seu efeito era risível, uma vez que "a gente lia aquelas cousas bonitas por obrigação e muito naturalmente as esquecia no mesmo instante".

Se, portanto, a forma livro correspondia às práticas saturadas de tradição, o jornal ou a revista eram concebidos como suportes mais adequados e atrativos para alavancar as práticas de leitura entre os jovens. Ademais, sob a aparência de cumprir uma função de entretenimento, eles também poderiam contribuir efetivamente para o exercício da instrução e do aprendizado. E, nesse momento, ele explicitava a sua aposta na necessidade de reinvenção do jornal infantil, como estratégia simultaneamente editorial e formativa, e, de quebra, reforçava também o caráter missionário dos escritores.

De jornais infantis portanto é que se precisa entre nós. Jornais que ensinem o Brasil antes de mais nada. Nacionalizem o brasileirinho. Inteligentemente. Nada de lorotas patrióticas e tropos auriverdes. Nada disso. Nesse gênero basta o Porque me ufano do meu país de triste fama. Mas abrasileirar divulgando por exemplo as nossas lendas indígenas ou não. Apresentando o sertão aos meninos da cidade. Acabar principalmente com essas historietas onde entram fadas louras, castelos, pagens e outras cousas inexistentes por aqui ou aqui inadaptáveis. Com material brasileiro construir os nossos contos de Perrault. (MACHADO, 1983c, p. 259-260).

Como se vê, o programa advogado por Alcântara Machado procurava tencionar as relações entre o nacional e o estrangeiro no que tange à invenção de um horizonte inovador que contemplasse tanto o conteúdo literário quanto a forma dos impressos destinados para o público infantil. No entanto, ele reconhecia que a solução era "tentador(a) mas quase impossível". Ele não oferecia uma dica sobre as razões que incidiam no quadro desolador, mas ponderava que se até mesmo "os marmanjos não tem o que ler o pessoal miúdo há de morrer certamente de fome literária. Ou então estragar o estômago com pães espirituais de massa nociva e mal cheirosa". Assim, ele descartava o apelo, "de modo meio antipático aliás”, feito por Gilberto Freyre e dirigido ao "grupo moderno de São Paulo para que escrevesse livros para meninos", como anunciava, de forma precursora, a necessidade de engendrar uma receita de finos biscoitos para serem oferecidos à gurizada.

Palavras loucas, ouvidos moucos e livros de qualidade duvidosa poderiam sintetizar o diagnóstico traçado pelo cronista sobre a situação experimentada pelo leitor juvenil. Não por acaso, ele descartava os produtos que circulavam por estas terras, formados na maioria das vezes por duas classes de livros, igualmente "estúpidos". Por um lado, as "novelas cinematográficas a duzentão o fascículo. De um romance de terceira classe. Escritas com os pés. Suando amor barato por todas 
as letras. Cretinizantes como elas só". E, de outro lado, uma série composta por "livros inocentes e distintos", designados como os "mais imbecis. Sem nenhum interesse para nós portanto. As bobagens da Condessa de Ségur crescem de tamanho ao calor brasileiro. E bobagens por bobagens antes as nossas. Ainda que bem crescidas". Este padrão de literatura tinha um efeito deformativo na construção do gosto literário das crianças e jovens, mas também era identificado no eugenismo presente na ficção lobatiana, particularmente o Choque das raças.

Considerando que a geração presente estava invariavelmente condenada pelas carências e pela força da tradição, Alcântara Machado lançava um clamor aos seus leitores: "Salvemos o porvir, meus senhores". A salvação estaria calcada na adoção de uma nova política cultural, ou, mais particularmente, no emprego de uma tática verificada na América do Norte e que também se disseminava na Europa, consistindo em um combate a ser desenvolvido em duas frentes. No front externo, ou mais distante, o desafio era fazer o livro procurar ou chegar às mãos dos leitores. E, para isso, ele exaltava o modelo do automóvel-biblioteca, que percorreria distantes paragens para abastecer literariamente "os lugarejos e as casas isoladas nos campos", tal qual preconizava a American Library Association. Já para o front interno, ele enaltecia o modelo das bibliotecas populares, descentralizadas, providas de bibliotecários incumbidos de estabelecer a mediação entre o desejo e as necessidades dos leitores e as potencialidades do acervo, bem como a implantação do serviço de distribuição "nos hospitais, nas prisões, nas oficinas, onde quer que se encontre um leitor".

Concebido com base na leitura de periódicos que remetiam às experiências estrangeiras, o plano para o porvir era sabidamente uma ideação. Por sua vez, Alcântara Machado se declarava não ser "tão ingênuo que pens(ass)e na possibilidade de se fazer cousa igual ou mesmo parecida aqui nesta terra". A configuração de um futuro patamar, novo e distinto, implicava a ruptura das fronteiras entre a alfabetização e a difusão do gosto pela leitura. De acordo com o cronista, "isso só pode(ria) ser feito com o auxílio das bibliotecas. Cousa sabida em toda a parte menos no Brasil".

O futuro da gurizada, concebida como partícipe ativa da modernização brasileira, deveria ter como esteio a criação de uma modalidade de biblioteca adequada a este público leitor. Dirigindo-se aos gestores e legisladores da cidade, o cronista se atribui o papel de porta-voz desta demanda, asseverando que "nada mais urgente e necessário do que a fundação de uma biblioteca pública infantil. Embora modesta para começar. Vocês verão: será muito mais frequentada dos que as duas que já possuímos. E prestará serviços de valor incomparavelmente maior”.

Embora consciente da relevância da proposta, Alcântara Machado vislumbrava com bastante ceticismo a possibilidade de implantação de uma política cultural que encampasse as suas propostas. Daí o tom melancólico com que fechava o artigo:

Os nossos administradores não tem tempo para perder com bobagens dessa ordem. A politicalha absorve inteiramente a maioria deles. $\mathrm{E}$ as crianças se quiserem ler que comprem nos pontos de jornais e revistas novelazinhas ordinárias e publicações picantes. Enquanto isso nas assembleias legislativas e nos relatórios administrativos se proclamará que a nacionalidade caminha avante.

Ai, ai, meu Deus do céu. (MACHADO, 1983c, p. 261).

\section{O QUE LEEM OS FUTUROS PROFESSORES?}

O debate sobre o mercado livreiro e os hábitos de leitura entre a população paulista não ficou restrito às colunas e aos rodapés dos jornais, tampouco ao saber e sabor dos críticos literários, editores, jornalistas e cronistas. Nesta quadra de "entusiasmo pela educação" (NAGLE, 1976, p. 111-112), o tema da leitura obviamente também ganhou espaço, sobretudo porque se articulava com o debate no campo político-pedagógico. Entre as muitas facetas e fissuras incluídas ali, destacavam-se as reformas educacionais, o embate entre conservadores, progressistas e católicos, a questão do método analítico e as novas perspectivas que incidiam tanto na formação 
dos professores normalistas como também no papel das escolas unificadas consideradas como "locus" da difusão de um logos nacional a ser assimilado pelos estudantes brasileiros e imigrantes.

É na condição de ativista no campo educacional, com uma forte inserção na imprensa paulistana, que Manoel B. Lourenço Filho publicou "Um inquérito sobre o que os moços leem" nas páginas do número inaugural da revista Educação, órgão da Diretoria Geral da Instrução Pública de São Paulo e da Sociedade de Educação, que naquele momento fazia parte da Associação Brasileira de Educação (ABE), na condição de seção paulista. De acordo com Ana Clara Bortoleto Nery, esta nova fase experimentada pela publicação encontrava-se inexoravelmente articulada à reconfiguração do campo educacional paulista, sobretudo a partir do "Inquérito sobre a situação do ensino público em São Paulo", promovido pelo jornal O Estado de S. Paulo, em 1926, sob a coordenação de Fernando de Azevedo, que teria por base a crítica à Reforma da Instrução de 1925 (NERY, 2009).

A reflexão proposta pela enquete levada a cabo por Lourenço Filho partia da constatação de que os jovens de 15 a 20 anos estavam muito distantes daquela "intensa febre de leitura, observada em estudantes de outros países", ressalvando ainda a necessidade de pensar "porque o pouco que se lê seja de medíocre qualidade". Partindo dessas considerações gerais, ele procurou definir o objetivo específico do inquérito, a saber, "conhecer o que tem lido, e como tem lido" o público-alvo formado pelo conjunto dos alunos da última série de duas escolas normais (uma delas da capital e outra, sem identificação, do interior do estado) e os alunos de um grande liceu da capital paulista.

Segundo Lourenço Filho, de nada valeria tentar paralelos com as experiências promovidas com o intuito de difusão do livro e da promoção da leitura por meio das bibliotecas públicas e populares estabelecidas nos Estados Unidos, Alemanha ou Suíça, uma vez que os recursos econômicos e as tradições culturais seriam elementos distintivos cuja comparação resultaria em um exercício equivocado. Contudo, ele não deixava de buscar respostas ou estímulos nas experiências concretas e contemporâneas implementadas no Uruguai e no México. Em grande medida, a difusão do livro e o estímulo à leitura nesses dois países passava por ações pautadas pelas:

edições populares custeadas pelo governo, oferecendo os grandes monumentos da literatura mundial pelo preço de um pão; são as bibliotecas circulantes, fáceis, cômodas, espalhadas por todos os cantos, ao lado do botequim e do cinema mais frequentado; quando não, essas curiosas livrarias ambulantes, às costas de um burro ou metidas na caixa de ônibus, que vão até a casa do leitor, na fazenda ou no campo, propiciando, insinuando, insistindo ao passatempo honesto e o ensino disfarçado... (LOURENÇO FILHO, 1927, p. 31).

Embora reconhecesse que o procedimento adotado para a elaboração do inquérito pudesse incorrer em imperfeições, uma vez que considerava "defeituosa a técnica empregada para a estatística rigorosa", ele admitia que ainda assim "permite chegar a valores significativos, como se poderá ver, pelas curvas de frequência traçadas". Resta, pois, saber como é que Lourenço Filho obteve o corpus documental que alicerçou sua investigação. Conforme relata, em uma aula em que encontrava condições mais propícias, ele lançava "uma sugestão ou um pedido" aos alunos:

E se verificássemos, então, quantos e que livros cada um dos senhores tem lido? Vejamos. Seria interessante. Tome cada um uma folha de papel e lápis. Eu vou fazer o mesmo. Cada qual, agora, ponha no cimo do papel a sua idade. Em seguida, um a um, os livros de que se lembram de ter lido e os respectivos autores, exceto, está claro, os livros obrigatórios do curso. Se não se lembrarem dos nomes dos autores, não importa; o que interessa mais é o nome da obra. Verificarei depois o autor. Vamos começar! Não será preciso assinar ou por o número do aluno. Sejam sinceros e façam todo o esforço de memória possível. Temos uma hora para isto... (LOURENÇO FILHO, 1927, p. 31-32). 
Depois de recolher o material produzido pelos alunos, ele tratou de organizá-los em três grupos gerais, compreendendo os dos alunos de cada uma das instituições, posteriormente separados pelo critério sexo e, finalmente, arranjados de acordo com grupos de idade próxima. Os sucessivos ajustamentos apoiavam-se em critérios de caráter sociológico e estatístico, nomeadamente a distinção entre os leitores da capital e do interior, a "influência da propaganda", os "interesses sentimentais", para o primeiro aspecto, e os "grupos homogêneos", os "valores significativos", as "realidades de observação ou pontos de referência", as "curvas de frequência" para a segunda vertente.

No que diz respeito aos aspectos quantitativos, especialmente no que tange à ênfase na frequência de obras por leitor, Lourenço Filho constatava não existirem grandes diferenças entre a leitura dos moços da mesma idade da capital e do interior. Da mesma forma, ele registrava que "não há, igualmente, diferença sensível na frequência do que leem, na mesma idade, rapazes e moças, de um ou de outro meio". Corroborando a apreciação dos dados quantitativos, ele registrou:

\footnotetext{
Os valores frequentes em todas as curvas, dadas as mesmas idades, coincidem impressionantemente, o que significa que a quantidade de leitura está ligada a razões sociais profundas, sensíveis no interior como aqui, sobre um sexo como noutro. Entre elas, não estará como último, por certo, o aspecto econômico da questão, revelado igualmente na preferência a certas obras e autores mais vulgarizados pelo baixo preço dos livros. Mas, por isso mesmo, causa tristeza a quantidade insignificante dos livros lidos! (LOURENÇO FILHO, 1927, p. 34).
}

Como ele pôde constatar, a experiência da leitura e o acesso aos livros estavam submetidos a uma série de variantes. Contudo, as determinações econômicas encontravam imensa ressonância, repercutindo diretamente na composição do cânone e no tipo de edição manipulada pelos leitores. Ao contrário da mera quantificação empregada, por exemplo, no inquérito do jornal $O$ Estado de S.Paulo, na presente enquete evidencia-se o emprego de métodos estatísticos que conferiam uma aura científica ao ensaio, afastando-o de qualquer conotação impressionista.

Com base nos dados obtidos com o grupo homogêneo formado por 86 moças cursando o último ano da Escola Normal de São Paulo, com idade entre 17 e 19 anos, Lourenço Filho teceu algumas significativas considerações sobre a leitura. Desprezando o emprego da média aritmética, ou ainda da mediana, ele optou por agrupar o número de indivíduos, ou frequência por leitor, de acordo com o número de livros lido por cada grupo. Dos 11 módulos traçados, com intervalos de uma dezena de livros, aquele que comportava o maior número de leitores havia lido entre 30 e 40 livros. Segundo o investigador, "é um resultado contristador" e mais adiante admitia que, mesmo considerando que o resultado pudesse ser duplicado, "ainda assim, seria desanimador. Quem até os dezoito anos leu sessenta livros apenas, nada leu". De certo, as operações estatísticas entabuladas pelo pesquisador atestavam os descaminhos da leitura entre aquele segmento que, mais ano, menos ano, seria responsável pela formação dos jovens estudantes.

Após perscrutar a quantidade de livros manipulados pelos distintos grupos homogêneos, Lourenço Filho tratou de analisar a frequência dos autores. O quadro abaixo reproduz na ordem decrescente o ranking dos autores mais visitados pelos leitores paulistas que colaboraram com o inquérito. 
Quadro 2 - Autores mais lidos pelos estudantes paulistas.

\begin{tabular}{|l|r|l|r|}
\hline $1^{\circ}$ & José de Alencar & $11^{\circ}$ & Georges Onhet \\
\hline $2^{\circ}$ & Madame Delly & $12^{\circ}$ & Alexandre Herculano \\
\hline $3^{\circ}$ & Joaquim M. de Macedo & $13^{\circ}$ & Guy de Chantepleure \\
\hline $4^{\circ}$ & Henri Ardel & $14^{\circ}$ & Paulo Setúbal \\
\hline $5^{\circ}$ & Machado de Assis & $15^{\circ}$ & Júlio Verne \\
\hline $6^{\circ}$ & Júlio Diniz & $16^{\circ}$ & Eça de Queiroz \\
\hline $7^{\circ}$ & Baronesa Von Brackel & $17^{\circ}$ & Victor Hugo \\
\hline $8^{\circ}$ & Bernardin de Saint Pierre & $18^{\circ}$ & Alexandre Dumas \\
\hline $9^{\circ}$ & Florance L. Barclay & $19^{\circ}$ & Pinheiro Chagas \\
\hline $10^{\circ}$ & Alfredo Taunay & $20^{\circ}$ & Paul Escrich \\
\hline
\end{tabular}

Fonte: LOURENÇO FILHO, Manoel B. "Um inquérito sobre o que os moços leem”. Educação, v.1, n. 1. São Paulo, out./1927, p. 27.

Ao ler a configuração acima, ele quase nada mencionava sobre o significado deste cânone, a diversidade de matrizes históricas e estilísticas representadas pelo conjunto de autores, ou, ainda, os valores estéticos e ideológicos associados aos escritores. Contudo, ele foi capaz de vislumbrar algumas dimensões que indicavam uma grande capacidade de ler estes dados a partir de um conjunto de prescrições e mediações cujas "conclusões parciais" são bastante significativas.

Segundo o educador, a ordem dos autores não se adequava a "um plano de cultura, não demonstra(va)m influências coordenadas, nem hierarquia, nem seleção". A observação foi reiterada ainda pela constatação de que o acervo de bibliotecas públicas e particulares era, em grande medida, formado de maneira "acidental", como também se constatava a ausência de diretrizes políticas específicas para a educação e a cultura. Diante do quadro de lacunas, ele preconizava formas de intervenção mais incisivas que deveriam partir desde as deliberações dos conselhos escolares até a "intervenção do Estado no mercado produtor, pela publicação de orientação de leitura".

Por sua vez, ele também interpretou a dispersão de cerca de 200 autores entre as 2.752 obras citadas como uma evidência de que "a maior e mais permanente influência que determina a escolha de autores é o fator econômico". Ou, como concisamente registrou, "o pouco que se lê é o que cabe à mão... o que é mais barato". E, para atestar a força deste pressuposto, ele tomou como exemplar o caso do escritor mais mencionado:

O fato de Alencar ter tido sempre, em todas as listas, a primazia da colocação não se deve ao fato de ser um grande romancista nacional, autor de muitas obras, autor moral e ainda perfeitamente de nosso tempo...Alencar é o autor mais ao alcance de todas as bolsas...Há dele horríveis edições mutiladas, de que os exemplares custam dez tostões. (LOURENÇO FILHO, 1927, p. 35-36).

Portanto, longe de explicitar um compromisso com um suposto programa de caráter nacionalista ou de um modelo cívico-pedagógico de formar os leitores, a mescla presente no quadro decorria da ação de importantes instâncias de mediação, a saber, de livreiros e bibliotecários, bem como da capacidade persuasiva empregada pela propaganda, pelos guias de consciência preconizados pelos católicos e os agentes do mercado. Dessa maneira, na tríade identificada com a tradição da literatura brasileira (Alencar, Macedo e Machado), figuravam autores franceses contemporâneos (Delly, Ardel, Barcklay, Chantepleure) que foram traduzidos e editados pela Companhia Editora Nacional, integrando a coleção "Biblioteca das Moças" (HALLEWELL, 2005, p. 343-358; TOLEDO, 2001; CUNHA, 1999, p. 51-104).

Finalmente, ao examinar o conjunto das 20 obras mais lidas entre as 83 jovens estudantes da Escola Normal de São Paulo, Lourenço Filho constatava a predileção pelas obras de ficção que remetiam em grande parte ao repertório romântico brasileiro. Em ordem decrescente, esta série de romances corresponderia aos títulos: Iracema $\left(1^{\circ}\right)$, O Tronco do Ipê $\left(2^{\circ}\right)$, A Moreninha $\left(3^{\circ}\right)$, O Guarani $\left(4^{\circ}\right)$, Helena $\left(6^{\circ}\right)$, Inocência $\left(16^{\circ}\right)$, Senhora $\left(17^{\circ}\right)$ e História de um Moço Loiro $\left(20^{\circ}\right)$. Neste 
mesmo quadro também figuravam obras de Madame Delly, como Escrava ou Rainha? $\left(5^{\circ}\right)$, Entre duas almas $\left(6^{\circ}\right)$ e Magali $\left(8^{\circ}\right)$; A filha do diretor de circo $\left(9^{\circ}\right)$, de Von Brackel, e outros títulos da Biblioteca das Moças, "recomendada pelos jornais católicos como leitura sã".

Para decepção do educador, o Machado de Assis selecionado pelas leitoras era aquele identificado com o entretenimento e a leitura fácil, não correspondendo ao autor incensado pela crítica, daí a diminuta referência ao Brás Cubas ou ao Quincas Borba. E, como que reforçando esta perspectiva acerca da leitura "de obras de limitado valor literário", ele sublinhava que "entre 60 livros mais lidos, alcançando a frequência de 60 a 14, não há um só livro de viagens ou de fundo; romances de tese, um ou dois; históricos, dois; tudo o mais, novelas e romances de 'ficelle" ". Se a permanência de Iracema e A Moreninha entre as práticas de leitura dos jovens de ambos os sexos indicava a inércia da literatura fundacional sob diferentes padrões editoriais disponibilizados pelo mercado, Lourenço Filho creditava a diminuição do interesse pelas novelas policiais, de tipo Sherlock Holmes, e de livros de viagem e de aventura, como os de Júlio Verne, "ao incremento do cinema".

Apesar de não conclusivo, o inquérito aberto por Lourenço Filho trazia para o centro do debate da Sociedade de Educação a "necessidade da organização de influências educativas quanto à leitura". Como que já adiantando algumas soluções para as debilidades programáticas e também para o estado de miséria dos equipamentos culturais presentes na cidade e no ambiente escolar, ele clamava: "Por que não insistir na organização de bibliotecas públicas pelas municipalidades? Por que não mostrar a necessidade das bibliotecas circulantes? Por que não chamar a atenção do próprio governo para uma obra direta nas escolas?" (LOURENÇO FILHO, 1927, p. 39).

\section{ARREMATE FINAL}

Conforme aventado no início do ensaio, há uma convergência temática e metodológica entre os textos selecionados, embora nem sempre se tenha verificado alguma forma de remissão entre si. Se, de fato, alguns textos denotam um exercício dialógico ou explicitam modos de apropriação e refutação de argumentos, é também importante sublinhar a existência de uma contiguidade temporal, uma vez que todos foram redigidos e publicados na década de 20 do século passado. Importa sublinhar que todos eles tiveram como suporte material aquela forma de comunicação associada à esfera da opinião pública, isto é, a folha impressa do jornal ou da revista.

Sob distintas perspectivas, os textos reunidos aqui são índices de um grande mal-estar compartilhado por políticos, intelectuais, pedagogos, escritores e homens ordinários que diziam respeito às formas de gestão e convergência entre os livros, a leitura e os equipamentos que viabilizariam o acesso à cultura letrada. A Era dos Inquéritos corresponde, pois, à ascensão de um grande debate sobre as políticas culturais que se tornarão práticas de ação governamental na década de 1930, na cidade de São Paulo, emblematizado, sobretudo, pelo programa do Departamento de Cultura e Recreação, encabeçado por Mário de Andrade (RAFFAINI, 2001).

Contudo, é preciso não se iludir com as promessas do nacionalismo populista que também emergia nesse contexto, em que se mesclavam exoticamente chauvinismo, folclore e vanguarda. Conforme advertiu sensatamente o historiador Nicolau Sevcenko, "é preciso questionar convicções que essa cadeia deixou empedernidas no nosso espírito", posto que:

Não é porque há eventos acontecendo e obras circulando que há cultura, assim como os ingleses sabem que não é porque há tâmaras no Natal que há tamareiras no país ou, inversamente, assim como os beduínos sabem que não há cerejas no deserto, mas pouco se importam, porque nem ligam para o Natal nem desejam as cerejas.

Não é pela possibilidade de repetir uma galeria de nomes consagrados ao infinito que uma cultura se mantém viva, isso é antes um sintoma do contrário. Assim como não é porque há uma legião de artistas, cientistas e intelectuais trabalhando com empenho, que uma atmosfera fértil e criativa está necessariamente sendo forjada. Não é da somatória 
das práticas e ações culturais que resulta um projeto de cultura integrado com o momento tecnológico e as demandas sociais" (SEVCENKO, 1993, p. 2).

\section{REFERÊNCIAS}

BASTOS, Maria Helena Câmara. Amada pátria idolatrada: um estudo da obra Porque me ufano do meu país, de Affonso Celso (1900). Educar em revista. Curitiba, n. 20, p. 245-260, dez. 2002.

BELLO, José Maria. À margem dos livros. Rio de Janeiro: Editora Anuário do Brasil, 1922, p. 123129. (Publicado originalmente sob o título "O movimento literário em São Paulo", coluna 'Vida Literária’, O Jornal. Rio de Janeiro, 05.02.1922, p.1).

BIGNOTTO, Cilza Carla. Figuras de autor, figuras de editor. As práticas editoriais de Monteiro Lobato. São Paulo: Ed. UNESP, 2018.

BONTEMPI JR., Bruno. O inquérito sobre a situação do ensino primário em São Paulo e suas necessidades (1914): análise das intervenções jornalísticas e políticas no discurso sobre a educação. Revista do Mestrado em Educação. UFS, v. 11, p. 43-50, 2005.

BROCA, José Brito. A Vida Literária no Brasil, 1900 (3ª ed.). Rio de Janeiro: José Olympio, 1975.

CAMARGO, Evandro do Carmo. Algumas notas sobre a trajetória editorial de O Saci. In:

LAJOLO, Marisa; CECCANTINI, João Luís (Orgs.). Monteiro Lobato, livro a livro: Obra infantil. São Paulo: Ed. UNESP/Imprensa Oficial do Estado de São Paulo, 2008, p. 87-99.

CUNHA, Maria Teresa Santos. As armadilhas da sedução. Os romances de M. Delly. Belo Horizonte: Autêntica, 1999.

EL FAR, Alessandra. Páginas de sensação. Literatura popular e pornográfica no Rio de Janeiro (18701924). São Paulo: Companhia das Letras, 2004.

HALLEWELL, Laurence. O livro no Brasil, sua história (2a ed.). São Paulo: EDUSP, 2005.

LOBATO, Monteiro. Os livros fundamentais. Obras completas v. 5 ( $8^{\mathrm{a} e d .) . ~ S a ̃ o ~ P a u l o: ~ B r a s i l i e n s e, ~}$ 1957, p. 83-88 (Publicado originalmente sob o título "Os livros fundamentais". Onda verde. São Paulo: Revista do Brasil, 1921).

LOURENÇO FILHO, Manoel B. Um inquérito sobre o que os moços leem. Educação. São Paulo, v. 1 n. 1, p. 27-39, out. 1927.

LUCA, Tania R. de. A Revista do Brasil: um diagnóstico para a (N)ação. São Paulo: Ed. UNESP, 1999.

MACHADO, António de Alcântara. Terra essencialmente agrícola. Obras v. 1 Prosa preparatória \& Cavaquinho e Saxofone. Rio de Janeiro: Civilização Brasileira/INL, 1983a, p. 174-179. (Publicado originalmente no Jornal do Commercio. São Paulo, 09/10/1926)

MACHADO, António de Alcântara. Cavaquinho. Obras v. 1 Prosa preparatória \& Cavaquinho e Saxofone. Rio de Janeiro: Civilização Brasileira/INL, 1983b, p. 192-196. (Publicado originalmente no Jornal do Commercio. São Paulo, 30/10/1926). 
MACHADO, António de Alcântara. Gurizada. Obras v. 1 Prosa preparatória \& Cavaquinho e Saxofone. Rio de Janeiro: Civilização Brasileira/INL, 1983c, p. 257-261. (Publicado originalmente no Jornal do Commercio. São Paulo, 12/03/1927).

MEYER, Marlyse. Tem mouro na costa ou Carlos Magno 'Reis' do Congo. Caminhos do Imaginário no Brasil. São Paulo: Edusp, 1993, p. 147-160.

NAGLE, Jorge Nagle. Educação e Sociedade na Primeira República (2 ed.). São Paulo: EPU, 1976.

NERY, Ana Clara Bortoleto. A Sociedade de Educação de São Paulo: embates no campo educacional (1922-1931). São Paulo: Ed. UNESP, 2009.

O QUE SE LÊ EM SÃO PAULO. O Estado de São Paulo (edição O Estadinho). São Paulo, 3 de julho de 1920 (Republicado sob o título "Movimento editorial". Revista do Brasil, n. 63. São Paulo, 1921, p. 278-280).

RAFFAINI, Patrícia Tavares. Esculpindo a Cultura na Forma Brasil. O Departamento de Cultura de São Paulo. 1936-1938. São Paulo: Humanitas, 2001.

RIO, João do. O Brasil lê. Livro - Revista do Núcleo de Estudos do Livro e da Edição. USP, n. 2, p. 334336, 2012 (Publicado originalmente em Gazeta de Notícias. Rio de Janeiro, 26/11/1903).

RIO, João do. O Momento Literário (edição e notas de Silvia Maria Azevedo e Tania Regina de Luca). São Paulo: Rafael Copetti Editor, 2019.

SEVCENKO, Nicolau. O Czar, o circo e as tamareiras. Folha de S. Paulo (Seção Tendências e Debates), 31/12/1993, p. 2.

TOLEDO, Maria Rita de Almeida. Coleção Atualidades Pedagógicas: do projeto político ao projeto editorial (1931-1981). Tese (Doutorado em Educação). São Paulo: PUC-SP, 2001.

Submetido: $05 / 04 / 2021$

Aprovado: 05/07/2021

Este artigo foi publicado em preprint e está disponível em: DOI: https://doi.org/10.1590/SciELOPreprints.2183 